\title{
Manure recycling from urban livestock farms for closing the urban-rural nutrient loops
}

\author{
Solomon Tulu Tadesse $(D)$ Oene Oenema $\cdot$ Christy van Beek $\cdot$ Fikre Lemessa Ocho
}

Received: 11 October 2018/Accepted: 4 November 2020/Published online: 22 November 2020

(C) The Author(s) 2020

\begin{abstract}
Rapid urbanization in developing countries is attracting urban livestock farming, which is associated with feed nutrient imports and manure nutrient accumulations. Here, we report on manure nutrients $(\mathrm{N}, \mathrm{P}$ and $\mathrm{K}$ ) production on urban livestock farms in Addis Ababa and Jimma in Ethiopia, and estimate manure recovery on these farms and its recycling in urban, peri-urban and rural crop farms. Estimates were based on data from farm surveys, statistics, literature and model calculations. Urban
\end{abstract}

Electronic supplementary material The online version of this article (https://doi.org/10.1007/s10705-020-10103-8) contains supplementary material, which is available to authorized users.

\section{S. T. Tadesse ( $\square)$}

Department of Soil Quality, Wageningen University and Research, P. O. Box 47, 6700 AA Wageningen, The Netherlands

e-mail: soltuta@gmail.com; solomon.tulu@ju.edu.et; solomon.tadesse@wur.nl

\section{S. T. Tadesse - F. L. Ocho}

Department of Horticulture and Plant Sciences, College of Agriculture and Veterinary Medicine, Jimma University, P. O. Box 307, Jimma, Ethiopia

O. Oenema

Wageningen Environmental Research,

P. O. Box 47, 6700 AA Wageningen, The Netherlands

C. van Beek

SoilCares Foundation, Nieuwe Kanaal 7c,

6709 PA Wageningen, The Netherlands livestock farms had on average 13 tropical livestock units and positive $\mathrm{N}, \mathrm{P}$ and $\mathrm{K}$ balances. Urban crop farms had negative $\mathrm{N}$ and $\mathrm{K}$ balances, and did not use manure from urban livestock farms. We estimated that 0.5-2.6 Gg N, 0.2-0.8 Gg P and 0.9-3.7 Gg K can be collected in manure from the 5,200 urban livestock farms in Addis Ababa year ${ }^{-1}$, and can be recycled in crop land. Two manure allocation strategies were explored: balanced $\mathrm{P}$ fertilization and balanced $\mathrm{N}$ fertilization. The former allowed greater precision in matching nutrient supply to demand, and was associated with greater manure transport and distribution, up to rural areas. Manure recycling has several benefits: synthetic fertilizer savings (75-300 million Ethiopian Birr year ${ }^{-1}$ for Addis Ababa), soil fertility replenishment, and reductions in water pollution. However, there are various cultural, educational and institutional barriers for manure recycling. We argue that more quantitative data and scenario analyses are needed for deliberative decision making and for exploring more sustainable development pathways of urban livestock farms, re-connected to crop farms via manure recycling.

Keywords Balanced fertilization · Fertilizer saving · Manure management $\cdot$ Nutrition security $\cdot$ Pollution 


\section{Introduction}

Global population is projected to reach $9-10$ billion by 2050 (FAO 2017) and 68\% of the population is projected to be urban (UN 2019). These changes are accompanied by fast growing food demand and dietary transitions in urban areas (Satterthwaite 2017). Most of the food for urban people is imported from rural areas (Jones et al. 2013), but significant amounts are provided also by urban and peri-urban farms (Roessler et al. 2016). Urban and peri-urban agriculture (UPA) contributes to the livelihood of urban dwellers, providing jobs, income and food security, especially in developing countries (Chihambakwe et al. 2018; Khumalo and Sibanda 2019; Mugisa et al. 2017). Thebo et al. (2014) reported that $11 \%$ of the global area of irrigated cropland was urban irrigated cropland, and $4.7 \%$ of global rain-fed cropland was urban. UPA farms mainly supply perishable vegetables and animal products to urban areas, due to the proximity to and high prices in urban markets (Djurfeldt 2015; Mugisa et al. 2017).

Significant amounts of nutrients are embedded in agricultural products that are transported from rural and peri-urban areas to urban areas (Lin et al. 2014; Zhu et al. 2017). This transfer contributes to nutrient accumulation in urban areas (Yu et al. 2017; Zhu et al. 2017) and to nutrient depletion in rural areas, especially when animal manure and human wastes from urban and peri-urban areas are not recycled back to rural areas (Goulding et al. 2008; Jones et al. 2013). The accumulation of manure and human waste in urban and peri-urban areas contributes to a range of unwanted human health and environmental effects (Herrero et al. 2018).

The 'circular economy' is a response to the inefficient use and management of resources in our current linear socio-economic systems (Michelini et al. 2017). It aims at more sustainable development through increased recycling. Alike, nutrient recovery from animal manure and human waste in urban and peri-urban areas and recycling in rural areas has direct environmental benefits (Rao et al. 2017; Neo 2010), and may replace synthetic fertilizers and thus reduce the costs, emissions and pollutions associated with the production and use of synthetic fertilizers (Buckwell and Nadeu 2016; Yu and Wu 2018). Also, recycled nutrients may reduce the dependency of countries on imports of fertilizers (Smits and Woltjer 2018), and are thought to have a vital role in achieving Sustainable Development Goals on food and nutrition security, clean water and sanitation, sustainable cities and life below water and on land (Zhu et al. 2017).

Although recycling of animal manures and household wastes has several advantages, the willingness and incentives for recycling manures and wastes back to crop land are still limited in developing countries (van Beek et al. 2016). For instance, less than $10 \%$ of the animal manures and crop residues available to smallholder farmers in Ethiopia were applied to soils (Nigussie et al. 2015), despite net nutrient depletion due to nutrient withdrawal with harvested crops, erosion and leaching, and limited applications of inorganic and organic fertilizers (van Beek et al. 2016). Some dung cakes are collected and used for building and cooking purposes, and some excrements deposited in animal confinements are partially recovered and applied to cropland, but most of the animal depositions are not recovered and recycled. There is lack of knowledge and information, and there are cultural barriers for recycling wastes. Moreover, governmental policies and regulations for manure collection and recycling are lacking (Komakech 2014; Tadesse et al. 2018) or incipient (Herrero et al. 2018) in developing countries. This leads to accumulation of nutrients in urban and peri-urban areas, and to pollution and eutrophication of rivers and lakes ( $\mathrm{Yu}$ et al. 2017).

Tackling nutrient accumulation in urban livestock farms and nutrient depletion in rural crop farms simultaneously, through recycling of manures from urban areas in rural areas, is an opportunity and a necessity (Goulding et al. 2008). Recycling of agricultural wastes is in line with the FAO model for sustainable intensification of crop production "Save and grow" (Pergola et al. 2017), and represents an important contribution to the circular economy at regional level (Pergola et al. 2017). However, the amounts of nutrients in manure that can be recycled from urban farms to rural farms, and the associated fertilizer savings are currently not well known. The purpose of this study was threefold: (i) to estimate the amounts of manure nutrients that can be recycled from urban livestock farms to crop farms in urban, periurban and rural areas, (ii) to explore strategies for increased manure recycling, and (iii) to estimate fertilizer saving and reductions in nutrient pollutions 
in urban, peri-urban and rural areas, in Addis Ababa and Jimma in Ethiopia.

\section{Materials and methods}

Study site and farm characteristics

Addis Ababa (Finfinnee) is the capital city of Ethiopia (Fig. S1); it had a total population of 3.4 million in 2015 and an annual population growth rate of $3.8 \%$ (Feyisa et al. 2016). Jimma is one of the secondary cities in Ethiopia and the commercial center of the Southwestern part of the country. It had a total population of 0.2 million in 2014 and an annual population growth rate of $3 \%$ (Abrha et al. 2015). The two cities differ in their bio-physical characteristics and agro-ecology. Addis Ababa has ten sub-cities; most of the UPA farms are found in five sub cities (Abdalla et al. 2011; Tadesse et al. 2019) and these were selected for this study. In Jimma, all eight urban woredas (districts) within the city were selected (Table S1). Rural woredas near the two cities were included (Table S1). Although the selected rural woredas are situated in the highlands and designated as models for the Agricultural Growth Program (AGP) woredas by the Ethiopian government, due to their potential for agricultural production (Eyasu and van Beek 2015; Tefera et al. 2012), the smallholder farms are not as productive as claimed (van Beek et al. 2016). Most UPA farms are mixed crop-livestock farms, but the relative contributions of crops, vegetables and livestock to farm income differs greatly. Farm income is much higher on farms with focus on livestock production and vegetables, than on farms with focus on crops (Tadesse et al. 2018). Most farms in the rural areas are also mixed crop-livestock farms (Table S1), but crop production is here the most important activity; livestock are kept for draught power supporting crop production and for family milk production (Mukai 2018).

\section{Concept of nutrient cycling between UPA farms and rural farms}

Urban, peri-urban and rural areas differ in population density, built-up areas, infrastructures and key economic activities (Allen 2003; Opitz et al. 2015). Makita et al. (2010) distinguished a city center with urban, peri-urban and rural areas around the center (Fig. 1). The city center is dominated by business buildings, high income residential areas and houses with high fences, and basically has no agriculture. Urban areas are densely populated built-up areas, with locally intensive farming activities. Peri-urban areas are urban-rural transition areas, with a high population increase, mainly through migration, and with space for agriculture. Rural areas have low population increase and often little economic activities; most people depend on agriculture, especially in developing countries. The width of the city center and urban and periurban areas greatly differ between cities and tend to increase over time when cities grow. Large cities have diameters of 30-50 km, and often exploit peri-urban and rural resources for urban uses (Simon 2008). However, the ecological, economic and social functions of rural areas are of mutual importance for urban, peri-urban and rural areas (Allen 2003).

City centers and urban, peri-urban and rural areas are often an asymmetrical, uneven and multi-dimensional continuum. There are no distinct lines separating the center from peri-urban, urban and rural settings, but often a slow zone of change exists (Lupindu 2017). For the purpose of our study, we distinguished three zones around the city centers of Addis Ababa and Jimma (Fig. 1). Addis Ababa had a city center of $527 \mathrm{~km}^{2}$ with a diameter of roughly $26 \mathrm{~km}$ in 2017 (Terfa et al. 2019), and Jimma a city center of $100 \mathrm{~km}^{2}$ with a diameter of roughly $11 \mathrm{~km}$ in 2017 (Abebe et al. 2019). Following the concept of

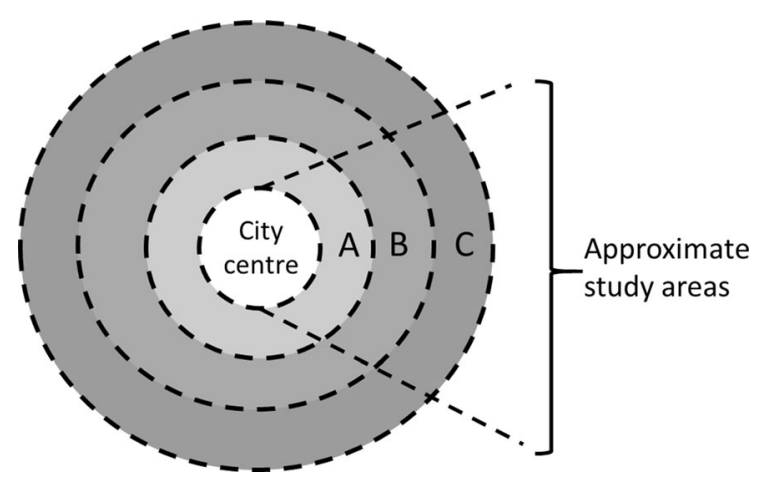

Fig. 1 Conceptual configuration of the studied cities, with a city center, and an urban zone (a), a peri-urban zone (b) and a rural zone (c) around the city center. The radius of the city center was estimated at $13 \mathrm{~km}$ and the width of each zone at $10 \mathrm{~km}$ for Addis Ababa, and at 6 and $5 \mathrm{~km}$ for Jimma, respectively. After Mohamed and Worku (2019) and Abrha et al. (2015) 
Zhu et al. (2017) and the approaches of Makita et al. (2010) and Opitz et al. (2015), we assigned three zones (A, B and C) around the city centers; $10 \mathrm{~km}$ wide zones around the city center of Addis Ababa, and $5 \mathrm{~km}$ wide zones around the city center of Jimma. Zone A is considered the 'urban periphery' (intra-urban). Zone B is the peri-urban area (urban-rural interface), and zone $\mathrm{C}$ is the rural area.

In each zone we identified the type, number and size of the farms on the basis of data statistics, literature and farms survey. In total, there were 5200 UPA livestock farms in Addis Ababa (Tamiru and Amza 2017) and 500 in Jimma (according to the agriculture office of the city). Tabor (2013) studied the land use of Addis Ababa and its fringes using Landsat images of 1973, 1986, 2000 and 2011 and collected land use data in 2011 for ground truthing (Table 1). Zewdie et al. (2018) also assessed the land use of Addis Ababa in 2015 using Landsat images of 1984, 1995, 2003 and 2014. The images were acquired during the dry seasons to better differentiate agricultural cropland from natural vegetation, and attained an accuracy level of $87 \%$ for land use classification (Zewdie et al. 2018). They estimated that the studied districts in Addis Ababa had an area of 122,100 ha, including 55,400 ha agricultural land (Admasu and Runnström 2017). Abrha et al. (2015) studied the land use of Jimma city using remote sensing and attained $84 \%$ accuracy level of land use classification. The studied districts in Jimma had an area of 12,000 ha, including 7,908 ha agricultural land.

We assumed that manure transport and recycling will occur in the following sequence. (i) Manure disposal is based on the $\mathrm{N}, \mathrm{P}$ and $\mathrm{K}$ demand of the crops; the nutrient element that meets the demand per crop/field first, determines the manure application rate (see also "Assessment of manure recycling" Section). (ii) The demand is satisfied (saturated) first in the zone where the manure has been produced, to minimize transport distances (Rodionov and Nakata 2011). (iii) Excess manure from zone $\mathrm{A}$ is transported to periurban crop farms in zone B, until also here all remaining demand has been satisfied. (iv) Remaining
Table 1 Land use and main crops in the studied districts of urban (A), peri-urban (B) and rural (C) areas of Addis Ababa and Jimma. For comparison, also data for a further rural area zone is presented. Note that total areas do match with areas of full circles. Sources: (Tadesse et al. 2019, 2018; Zewdie et al. 2018; Abrha et al. 2015)

\begin{tabular}{|c|c|c|c|c|c|c|}
\hline \multirow{2}{*}{\multicolumn{2}{|c|}{$\begin{array}{l}\text { Land use types (ha) } \\
\text { Addis Ababa }\end{array}$}} & \multicolumn{4}{|c|}{ Distances of zones from city centers $(\mathrm{km})$} & \multirow[t]{2}{*}{ Total } \\
\hline & & $A(0-10)$ & $B(10-20)$ & $C(20-30)$ & $30-40$ & \\
\hline \multicolumn{2}{|l|}{ Built-up } & 32,462 & 16,632 & 3,368 & 2738 & 55,200 \\
\hline \multicolumn{2}{|l|}{ Agriculture } & 658 & 24,539 & 24,398 & 5805 & 55,400 \\
\hline \multicolumn{2}{|c|}{ Main crops cultivated } & $\begin{array}{l}\text { Vegetables (e.g. } \\
\text { tomato, } \\
\text { potato), beans }\end{array}$ & $\begin{array}{l}\text { Vegetables, beans, } \\
\text { barley, wheat, pulses }\end{array}$ & $\begin{array}{l}\text { Barley, teff, } \\
\text { wheat, pulses }\end{array}$ & $\begin{array}{l}\text { Barley, teff, wheat, } \\
\text { high land } \\
\text { oilseeds, pulses }\end{array}$ & \\
\hline Vegetation & & 3688 & $5,681.3$ & $1,738.4$ & 392.3 & 11,500 \\
\hline Total & & 36,808 & $46,852.3$ & $29,504.4$ & 8935.3 & 122,100 \\
\hline \multirow{2}{*}{$\begin{array}{l}\text { Land use } \\
\text { types (ha) } \\
\text { Jimma }\end{array}$} & \multicolumn{5}{|c|}{ Distances of zones from city centers $(\mathrm{km})$} & \multirow[t]{2}{*}{ Total } \\
\hline & \multicolumn{2}{|l|}{$A(0-5)$} & $B(5-10)$ & $C(10-15)$ & $15-20$ & \\
\hline Built-up & \multicolumn{2}{|l|}{632} & 628 & 0 & 0 & 1260 \\
\hline Agriculture & \multicolumn{2}{|l|}{992} & 2478 & 2544 & 1,894 & 7908 \\
\hline $\begin{array}{r}\text { Main crops } \\
\text { cultivated }\end{array}$ & \multicolumn{2}{|c|}{$\begin{array}{l}\text { Vegetables (e.g. tomato, } \\
\text { potato), beans }\end{array}$} & $\begin{array}{l}\text { Vegetables, beans, maize, } \\
\text { barley, wheat }\end{array}$ & $\begin{array}{l}\text { Barley, teff, } \\
\text { wheat, coffee }\end{array}$ & $\begin{array}{l}\text { Teff, sorghum maize, wheat, } \\
\text { coffee, spices }\end{array}$ & \\
\hline Vegetation & \multicolumn{2}{|l|}{908} & 1399 & 428 & 97 & 2832 \\
\hline Total & \multicolumn{2}{|l|}{2532} & 4505 & 2972 & 1991 & 12,000 \\
\hline
\end{tabular}

Note that the three zones defined for the envisaged recycling are indicated in italic 
surpluses from zone A (and possibly from zone B) are then transported to rural crop farms in zone $\mathrm{C}$.

\section{Data collection}

In 2014, a total of 299 UPA farms (Addis Ababa: 175, Jimma: 124) were visited and examined; the diversity among the farms and the $\mathrm{N}, \mathrm{P}$ and $\mathrm{K}$ balances have been reported by Tadesse et al. (2018). In 2016, a random selection of 40 livestock farms (Addis Ababa: 20, Jimma: 20) and 38 crop farms (Addis Ababa: 19, Jimma: 19) out of the 299 UPA farms were revisited and examined in more detail. In 2016 we also visited 164 farms in rural areas: 72 from five rural woredas (districts) linked to Addis Ababa, and 92 from five rural woredas linked to Jimma. Farmers were interviewed face-to-face and data was collected using the standardized questionnaire of MonQIt (Monitoring for Quality Improvement toolbox) (van Beek et al. 2010, 2016).

MonQIt is a toolbox for monitoring and evaluating the management and performance of smallholder farms (www.monqit.com; Smaling et al. 2013; Vlaming 2012). The information about farm management and farm activities is obtained from the farmer using the MonQIt questionnaire (see the supplementary information). The following data were collected: farm characteristics, crop and animal husbandry practices, nutrient management (inputs via fertilizer, manure, crop residues; outputs via harvested crops and animal products), sales, and input and output prices. The data were entered into the MonQIt model, which also contains a data base with information on nutrient contents of products, soil data and conversion factors. The MonQIt model produces the following performance indicators: NPK balances at plot, activity and farm levels, and gross margin and net farm income (van Beek et al. 2016).

The 78 UPA farms and 164 farms in the rural area were visited twice in 2016. In the first round, farm characteristics and nutrient input flows (purchased mineral fertilizers, organic fertilizers, seeds, feed and concentrates) were quantified at the beginning of the cropping season. In the second round, output flows (harvested crop products, residues and animal products, and sales) leaving the farm were quantified after harvest. Data on nutrient (N, P and K) contents of harvested crop products, crop residues, milk and manure were obtained from literature (Alvarez et al.
2014; Negash et al. 2017; Wang et al. 2016) and included in the MonQIt database.

Quantification of farm level nutrient balances

The N, P and $\mathrm{K}$ input and output flows were estimated as follows (Bekunda and Manzi 2003; Nigussie et al. 2015):

$F=\sum_{i=1}^{n} Q i \mathrm{DiC} i$

where, $\mathrm{F}$ is the flow of $\mathrm{N}, \mathrm{P}$ or $\mathrm{K}\left(\mathrm{kg} \mathrm{ha}^{-1} \mathrm{yr}^{-1}\right)$; $\mathrm{n}$ is the number of nutrient inputs and outputs in a year; $\mathrm{Q}$ is the quantity of inputs or outputs $\left(\mathrm{kg} \mathrm{ha}^{-1} \mathrm{yr}^{-1}\right)$; $\mathrm{D}$ is the dry matter content of inputs or outputs (\%); $\mathrm{C}$ is $\mathrm{N}$, $\mathrm{P}$ or K content of inputs or outputs (\%).

Nutrient (N, P and K) balances were calculated per farm as the difference between total input and total output flows of N, P and K, annually (Eq. 2; unit: $\mathrm{kg}$ $\mathrm{ha}^{-1} \mathrm{yr}^{-1}$ ):

$N B=[(I N 1+\ldots+I N 4)-(O U T 1+\ldots+$ OUT5 $)]$

where, NB is nutrient balance; IN1 and IN2 are farmer managed inputs (fertilizer, compost, concentrate, organic feed), IN3 and IN4 are atmospheric deposition and biological N fixation, respectively, and OUT1 and OUT2 are outputs in harvested crop, residue, milk and manure and OUT3, OUT4 and OUT5 are losses via leaching, gaseous emissions and erosion, respectively (van Beek et al. 2016).

Net farm income (NFI) was derived from gross margin (GM) and the total fixed costs (FIXCOST) of the farm (Eq. 3; unit: Ethiopian Birr $\mathrm{yr}^{-1}$ ).

$\mathrm{NFI}=\mathrm{GM}-\mathrm{FIXCOST}$

where, GM is calculated as the difference between the gross value of all outputs and the variable costs of all inputs of the farm, over a year. FIXCOST is the total fixed costs of the farm (e.g. depreciation costs of barns, tools, and rent of the land).

Assessment of manure recycling

In total, there were about 5200 urban livestock farms in Addis Ababa (Tamiru and Amza 2017) and 500 LS farms in Jimma (according to the information obtained from the urban agriculture office of the city) in 2016. 
In general, these farms had dairy cattle, on average 13.5 tropical livestock units (TLU) in Addis Ababa and 11.5 TLU in Jimma (Table 2). Manure production was calculated according to Eq. 4.

$$
\begin{aligned}
& \text { Manure } N, P \text { and } K \text { production per zone }(\mathrm{kg}) \\
& \quad=\text { Number of farms per zone } * \text { average } T L U \text { per farm } \\
& \quad * \text { average manure } N, P, K \text { per TLU }
\end{aligned}
$$

Estimates of manure production per animal, in $\mathrm{kg}$ N, P and K per tropical livestock unit (TLU; 1 TLU has a live weight of $250 \mathrm{~kg}$ ), were based on literature data and farm surveys. Snijders et al. (2009) arrived at average manure production of $9.43 \mathrm{~kg} \mathrm{TLU}^{-1}$ day $^{-1}$ (fresh weight), with a dry matter content of $35 \%$. This translates to an annual manure production of $25 \mathrm{~kg} \mathrm{~N}$, $6.7 \mathrm{~kg} \mathrm{P}$, and $33 \mathrm{~kg} \mathrm{~K}$ per TLU, when assuming mean contents of $2.1 \% \mathrm{~N}, 0.56 \% \mathrm{P}$, and $2.75 \% \mathrm{~K}$ (Negash et al. 2017). Sheldrick et al. (2003) estimated the global manure N, $\mathrm{P}$ and $\mathrm{K}$ production based on linear relationships between slaughtered weight and N, P and $\mathrm{K}$ production. Using their model, we arrive at an annual manure production of $28 \mathrm{~kg} \mathrm{~N}, 5.6 \mathrm{~kg} \mathrm{P}$ and $25 \mathrm{~kg} \mathrm{~K}$ per TLU (with a slaughtered weight for cattle of $140 \mathrm{~kg} \mathrm{TLU}^{-1}$ ). Snijders et al. (2009) reviewed variations in cattle manure composition and management practices in East Africa. Variations in nutrient content of manures were large and associated with differences in (i) feed rations, (ii) collection, storage and processing of excreta, and (iii) additions of bedding materials. Further, excretion rates were related to milk production; they indicated that milk production ranged from $<500 \mathrm{~kg}$ to more than 4500 $\mathrm{cow}^{-1}$ year $^{-1}$, and that manure $\mathrm{N}$ production ranged from 30 to $90 \mathrm{~kg} \mathrm{cow}^{-1}$ year $^{-1}$. Our survey data also revealed large variability in cattle productivity and management between livestock farms; based on these observations we decided to use three sets of manure $\mathrm{N}$, $\mathrm{P}$, and $\mathrm{K}$ production coefficients: 25,5 and $25 \mathrm{~kg}$ cow $^{-1}$ year $^{-1}$ for cows producing $<500 \mathrm{~kg}$ milk year $^{-1} ; 50,10$ and $50 \mathrm{~kg} \mathrm{cow}^{-1}$ year $^{-1}$ for cows producing 500 to $3000 \mathrm{~kg}$ milk year $^{-1}$, and 75,15 and $75 \mathrm{~kg} \mathrm{cow}^{-1}$ year $^{-1}$ for cows producing $>3000 \mathrm{~kg}$ milk year ${ }^{-1}$, respectively. Hence, N: P: K ratios (5:1:5) in excreta were kept constant. Further, we assumed that young stock (calves and heifers) produced on average $25 \%$ of the amounts of adult cows.
Manure recovery fractions (RF) are defined as the fractions of $\mathrm{N}, \mathrm{P}$ and $\mathrm{K}$ excreted in manures that are recovered for recycling. These fractions mainly depend on the manure collection efficiency and nutrient losses during storage. Snijders et al. (2009) estimated nutrient losses for different manure collection and storage systems for East African conditions. Losses were highest for open kraal/boma (30-100\% for urine N; 10-50\% for faeces N, 20-30\% for faeces P and $10-80 \%$ for $\mathrm{K}$ ) and least for leak tight and covered slurry pits (20-40\% for urine $\mathrm{N} ; 5-10 \%$ for faeces $\mathrm{N}$, 3-10\% for faeces P and 5-15\% for K). Liu et al. (2017) estimated recovery fractions of $0.3-0.7$ for $\mathrm{N}$ and 0.5 to $0.95 \%$ for $\mathrm{P}$ as function of housing systems and manure management. A recovery fraction of 0.3 indicates poor manure management whereas 0.95 indicates best manure management (Liu et al. 2017). Rufino et al. (2007) reported a recovery of 0.4 for $\mathrm{N}$ in manure stored in open piles in Kenya. Bicudo (2009) and Sutton (1994) reported recovery fractions of 0.4-0.6 for $\mathrm{N}, 0.6-0.8$ for $\mathrm{P}$ and $0.5-0.7$ for $\mathrm{K}$ in manures from open manure storages. Most livestock farms in Addis Ababa and Jimma have no leak-tight stables and manure storage systems (Tadesse et al. 2019), but recovery fractions have not been quantified. Based on this data, we used two sets of recovery fractions for $\mathrm{N}, \mathrm{P}$ and $\mathrm{K}$ in manure: $0.3-0.5$ for $\mathrm{N}$, 0.6-0.8 for $\mathrm{P}$, and $0.5-0.7$ for $\mathrm{K}$. The recyclable amounts of N, P and $\mathrm{K}$ in manure were estimated from the manure $\mathrm{N}, \mathrm{P}$ and $\mathrm{K}$ production per zone and the recovery fractions.

Total $\mathrm{N}, \mathrm{P}$ and $\mathrm{K}$ demands were estimated from crop-specific N, P and $\mathrm{K}$ demands $\left(\mathrm{kg} \mathrm{ha}^{-1}\right.$ year $^{-1}$ ) per zone, crop type-specific nutrient losses (van Beek et al. 2016), and surface areas of the crops per zone, using MonQIt (van Beek et al. 2016). The fraction of the $\mathrm{N}, \mathrm{P}$ and $\mathrm{K}$ demand covered through recycling per zone depended on the specific crop demands, the manure composition and manure application strategy. Two variants of manure application strategies were explored: (i) balanced $\mathrm{P}$ application, i.e., manure application defined by $\mathrm{P}$ demand (and assuming top-up $\mathrm{N}$ and/or $\mathrm{K}$ fertilization through other nutrient sources), and (ii) balanced $\mathrm{N}$ fertilization, i.e., manure application defined by $\mathrm{N}$ demand (and thus accepting over fertilization of $\mathrm{P}$ and/or $\mathrm{K}$ ). 
Data analysis

Data obtained from MonQIt model on nutrient flows, balances, farm characteristics (e.g. TLU and farm size) and economic performance indicators (e.g. net farm income) per farm were subjected to ANOVA to test for significant differences in nutrient flows and balances, net farm income and farm characteristics among urban, peri-urban and rural farms. Mean values of nutrient flows and balances were compared using LSD value at 5\%. For all data analysis, we used SPSS statistical software version 23 .

\section{Results}

\section{Farm characteristics}

Farms were relatively small, with on average 0.6-2.6 ha of land per household (Table 2). Households had on average 7 family members, both in the urban and rural areas. Urban livestock farms had on average 11.5-13.5 tropical livestock units (TLU) per farm, peri-urban farms 5-6 and rural farms 6-7 TLU. Urban crop farms also had 4-7 TLU per farm; basically, these were mixed crop-livestock farms. Livestock density was high; in Addis Ababa urban livestock farms had $>22$ TLU per ha of land and in
Jimma 16 TLU per ha. Even the rural farms in both Addis Ababa and Jimma had a livestock density of 2-3 TLU per ha.

Farm characteristics were slightly different between the farms in Addis Ababa and Jimma regions (Table 2). UPA farms in Addis Ababa had more livestock, less crop area and less crops per farm than the UPA farms in Jimma. As a result, UPA farms in Addis Ababa had on average a higher net farm income than the UPA farms in Jimma (Table 2).

Farm level nutrient flows and balances

Nutrient balances were significantly different $(P<0.05)$ among urban livestock farms and crop farms in urban, peri-urban and rural areas (Table 3). Crop farms had negative $\mathrm{N}$ and $\mathrm{K}$ balances, and positive $\mathrm{P}$ balances, in all three zones. This indicates soil $\mathrm{N}$ and $\mathrm{K}$ depletion and soil $\mathrm{P}$ accumulation. Positive $\mathrm{P}$ balances on crop were related to the use of subsidized di-ammonium phosphate (DAP) fertilizers. Note that the N, P and K output of crop farms include losses via leaching, erosion and denitrification. As a result, the estimated N/P ratios of the output ranged from 10 to as high as 40 , and $\mathrm{K} / \mathrm{P}$ ratios of the output ranged from 2 to 6 .

Positive N, P and K balances of livestock farms were related to the import of animal feed to the farm,

Table 2 Mean characteristics (standard deviations between brackets) of urban livestock (LS) and crop farms, and of peri-urban and rural farms in Addis Ababa and Jimma (2016 monitoring year)

\begin{tabular}{|c|c|c|c|c|c|c|c|c|}
\hline \multirow[t]{3}{*}{ Characteristics } & \multicolumn{4}{|c|}{ Addis Ababa } & \multicolumn{4}{|l|}{ Jimma } \\
\hline & \multicolumn{2}{|l|}{ Urban } & \multirow{2}{*}{$\begin{array}{l}\text { Peri-urban } \\
(\mathrm{n}=11)\end{array}$} & \multirow{2}{*}{$\begin{array}{l}\text { Rural } \\
(\mathrm{n}=72)\end{array}$} & \multicolumn{2}{|l|}{ Urban } & \multirow{2}{*}{$\begin{array}{l}\text { Peri-urban } \\
(\mathrm{n}=9)\end{array}$} & \multirow{2}{*}{$\begin{array}{l}\text { Rural } \\
(\mathrm{n}=92)\end{array}$} \\
\hline & $\begin{array}{l}\mathrm{LS} \\
(\mathrm{n}=20)\end{array}$ & $\begin{array}{l}\text { Crop } \\
(\mathrm{n}=8)\end{array}$ & & & $\begin{array}{l}\mathrm{LS} \\
(\mathrm{n}=20)\end{array}$ & $\begin{array}{l}\text { Crop } \\
(\mathrm{n}=10)\end{array}$ & & \\
\hline $\begin{array}{l}\text { Number of household } \\
\text { (HH) members }\end{array}$ & $7( \pm 3)$ & $6( \pm 4)$ & $6( \pm 3)$ & $7( \pm 2)$ & $5( \pm 2)$ & $7( \pm 2)$ & $7( \pm 2)$ & $7( \pm 2)$ \\
\hline $\begin{array}{l}\text { Ratio of female to } \\
\text { male HH head (F:M) }\end{array}$ & $1: 6$ & $1: 3$ & $1: 4.5$ & $1: 6$ & $1: 4$ & $0: 10$ & $0: 9$ & $1: 12$ \\
\hline $\begin{array}{l}\text { Land size per farm } \\
\text { of HH (ha) }\end{array}$ & $0.6( \pm 0.4)$ & $1.7( \pm 0.9)$ & $1.7( \pm 0.8)$ & $2.0( \pm 1.5)$ & $0.7( \pm 0.4)$ & $1.5( \pm 0.8)$ & $1.4( \pm 0.7)$ & $2.6( \pm 1.4)$ \\
\hline $\begin{array}{l}\text { Number of crops per } \\
\text { farm }\end{array}$ & $1( \pm 1)$ & $6( \pm 1)$ & $5( \pm 2)$ & $3( \pm 1)$ & $2( \pm 3)$ & $7( \pm 2)$ & $5( \pm 2)$ & $6( \pm 2)$ \\
\hline $\begin{array}{l}\text { Number of livestock } \\
\text { per farm (TLU) }\end{array}$ & $13.5( \pm 9)$ & $4( \pm 7)$ & $6( \pm 3)$ & $7( \pm 4)$ & $11.5( \pm 7)$ & $7( \pm 5)$ & $5( \pm 2)$ & $6( \pm 3)$ \\
\hline $\begin{array}{l}\text { Net farm income } \\
\quad(1000 \mathrm{ETB} / \mathrm{ha} / \text { year })^{\text {a }}\end{array}$ & $527( \pm 258)$ & $117( \pm 93)$ & $84( \pm 62)$ & $20( \pm 18)$ & $474( \pm 295)$ & $35( \pm 32)$ & $60( \pm 103)$ & $11( \pm 8)$ \\
\hline
\end{tabular}

${ }^{\mathrm{a}} 1000$ ETB (Ethiopian Birr) $=30$ US\$ (April 2020) 
Table 3 Mean nutrient inputs, outputs and balances $\left(\mathrm{kg} \mathrm{ha}^{-1} \mathrm{year}^{-1}\right)$ of urban livestock (LS) and crop farms, and peri-urban and rural crop farms in Addis Ababa and Jimma

\begin{tabular}{|c|c|c|c|c|c|c|c|c|}
\hline \multirow[t]{3}{*}{ Variables } & \multicolumn{4}{|c|}{ Addis Ababa Farms } & \multicolumn{4}{|c|}{ Jimma Farms } \\
\hline & \multicolumn{2}{|l|}{ Urban } & \multirow{2}{*}{$\begin{array}{l}\text { Peri-urban } \\
(\mathrm{n}=11)\end{array}$} & \multirow{2}{*}{$\begin{array}{l}\text { Rural } \\
(\mathrm{n}=72)\end{array}$} & \multicolumn{2}{|l|}{ Urban } & \multirow{2}{*}{$\begin{array}{l}\text { Peri-urban } \\
(\mathrm{n}=9)\end{array}$} & \multirow{2}{*}{$\begin{array}{l}\text { Rural } \\
(\mathrm{n}=92)\end{array}$} \\
\hline & $\begin{array}{l}\mathrm{LS} \\
(n=20)\end{array}$ & $\begin{array}{l}\text { Crop } \\
(n=8)\end{array}$ & & & $\begin{array}{l}\mathrm{LS} \\
(\mathrm{n}=20)\end{array}$ & $\begin{array}{l}\text { Crop } \\
(n=10)\end{array}$ & & \\
\hline $\begin{array}{l}\text { Nitrogen } \\
(\mathrm{N}) \text { balance }\end{array}$ & $343^{\mathrm{a}}$ & $-81^{b}$ & $-43^{b}$ & $-49^{\mathrm{b}}$ & $314^{\mathrm{a}}$ & $-41^{\mathrm{b}}$ & $-73^{\mathrm{b}}$ & $-28^{\mathrm{b}}$ \\
\hline $\mathrm{N}$ input & $534^{\mathrm{a}}$ & $87^{\mathrm{b}}$ & $105^{\mathrm{b}}$ & $80^{\mathrm{b}}$ & $424^{\mathrm{a}}$ & $69^{\mathrm{b}}$ & $37^{\mathrm{b}}$ & $39^{\mathrm{c}}$ \\
\hline $\mathrm{N}$ output & $191^{\mathrm{a}}$ & $168^{\mathrm{a}}$ & $148^{\mathrm{a}}$ & $129^{\mathrm{a}}$ & $110^{\mathrm{a}}$ & $110^{\mathrm{a}}$ & $110^{\mathrm{a}}$ & $67^{\mathrm{b}}$ \\
\hline $\begin{array}{l}\text { Phosprous } \\
\text { (P) balance }\end{array}$ & $53^{\mathrm{a}}$ & $6^{\mathrm{b}}$ & $24^{\mathrm{b}}$ & $14^{\mathrm{b}}$ & $54^{\mathrm{a}}$ & $14^{\mathrm{b}}$ & $3^{b}$ & $10^{\mathrm{b}}$ \\
\hline $\mathrm{P}$ input & $82^{\mathrm{a}}$ & $23^{\mathrm{b}}$ & $30^{\mathrm{b}}$ & $17^{\mathrm{b}}$ & $57^{\mathrm{a}}$ & $18^{\mathrm{b}}$ & $12^{\mathrm{b}}$ & $13^{\mathrm{b}}$ \\
\hline P output & $29^{\mathrm{a}}$ & $17^{\mathrm{a}}$ & $6^{\mathrm{b}}$ & $3^{b}$ & $3^{\mathrm{a}}$ & $4^{\mathrm{a}}$ & $9^{\mathrm{a}}$ & $3^{\mathrm{a}}$ \\
\hline $\begin{array}{l}\text { Potassium } \\
\text { (K) balance }\end{array}$ & $187^{\mathrm{a}}$ & $-79^{b}$ & $-9^{b}$ & $-11^{\mathrm{b}}$ & $189^{\mathrm{a}}$ & $1^{\mathrm{b}}$ & $-8^{\mathrm{b}}$ & $-1^{b}$ \\
\hline $\mathrm{K}$ input & $280^{\mathrm{a}}$ & $24^{\mathrm{b}}$ & $22^{\mathrm{b}}$ & $6^{\mathrm{b}}$ & $194^{\mathrm{a}}$ & $17^{\mathrm{b}}$ & $12^{\mathrm{b}}$ & $5^{\mathrm{b}}$ \\
\hline K output & $93^{\mathrm{a}}$ & $103^{\mathrm{a}}$ & $31^{\mathrm{b}}$ & $17^{\mathrm{b}}$ & $5^{\mathrm{b}}$ & $16^{\mathrm{a}}$ & $20^{\mathrm{a}}$ & $6^{\mathrm{b}}$ \\
\hline
\end{tabular}

ANOVA was used to compare continuous variables and means were compared using LSD test

Means with different letters within rows per city are significantly different

Balances of $\mathrm{N}\left(F_{3,117}=65.2\right), \mathrm{P}\left(F_{3,117}=10.9\right)$ and $\mathrm{K}\left(F_{3,117}=14.7\right)$ at Addis Ababa and $\mathrm{N}\left(F_{3,127}=38.6\right), \mathrm{P}\left(F_{3,127}=25.6\right)$ and $\mathrm{K}$ $\left(F_{3,127}=41.8\right)$ at Jimma, all significantly differed at $p<0.05$ among 4 farm groups: urban livestock farms, urban, peri-urban and rural crop farms (2016 monitoring year)

and to the fact that only a small fraction (5-20\%) of the ingested feed $\mathrm{N}, \mathrm{P}$ and $\mathrm{K}$ is exported in milk and meat. The remainder of the ingested feed $\mathrm{N}, \mathrm{P}$ and $\mathrm{K}$ is excreted in urine and faeces. Note that the output of $\mathrm{N}$, $\mathrm{P}$ and $\mathrm{K}$ of livestock farms were not corrected for losses from manure storage systems in Table 3. The N, $\mathrm{P}$ and $\mathrm{K}$ output of urban livestock farms were higher in Addis Ababa than in Jimma, mainly because of the higher animal productivity and higher crop yields in Addis Ababa. We infer that significant amounts of surplus manures from urban livestock farms can be recycled to nearby crop farms.

Potentials of manure nutrient recycling

We estimated that $0.5-2.6 \mathrm{Gg} \mathrm{N}, 0.2-0.8 \mathrm{Gg} \mathrm{P}$ and 0.9-3.7 Gg K may be collected in manure from urban livestock farms in Addis Ababa and recycled to crop land per year (Table 4). The ranges reflect the uncertainty (roughly a factor 3 ) in the estimates due to the variation in $\mathrm{N}, \mathrm{P}$ and $\mathrm{K}$ excretion coefficients, and in $\mathrm{N}, \mathrm{P}$ and $\mathrm{K}$ recovery fractions (variants 1 to 6 ). The estimated quantities were more than one order of magnitude lower for Jimma: $0.04-0.22 \mathrm{Gg} \mathrm{N}$, 0.02-0.07 Gg P and 0.07-0.30 Gg K (Table 4), because the size and the number of urban livestock farms were less in Jimma than in Addis Ababa.

Total N, P and K demands by crop-based farms were much smaller in the urban area than in the periurban and rural areas (Table 5). The mean N/P ratio of the demand was 7 and the mean $\mathrm{K} / \mathrm{P}$ ratio was 6 , with little differences between Addis Ababa and Jimma, and between zones A, B and C. Figure 2 presents the supply of manure N, P, and K from urban livestock farms relative to the demand of $\mathrm{N}, \mathrm{P}$ and $\mathrm{K}$ by cropbased farms in the three zones $\mathrm{A}, \mathrm{B}$ and $\mathrm{C}$, for six variants and two application strategies. The N/P ratios in the available manure ranged from 2.5 to 3.1 , and the $\mathrm{K} / \mathrm{P}$ ratio from 4.2 to 4.4 (Table 4 ), and were much lower than the N/P and K/P ratios of the demand by the crop farms. As a result, the $\mathrm{N}$ and $\mathrm{K}$ demand by the crop was not matched by $\mathrm{N}$ and $\mathrm{K}$ supply by manure in the urban area, if manure application rates were determined by balanced P fertilization (Fig. 2a). The same applies for the peri-urban and rural areas; in Addis Ababa there were three variants (4, 5 and 6) that 
Table 4 Amounts of recyclable N, P, and K in manure in Addis Ababa and Jimma urban regions, as function of variants (combinations of 3 sets of excretion coefficients and 2 sets of recovery fractions; see text)

\begin{tabular}{|c|c|c|c|c|c|c|c|c|c|c|}
\hline \multirow[t]{2}{*}{ Cities } & \multirow[t]{2}{*}{ Variant } & \multicolumn{3}{|c|}{ Excretion rates $\left(\mathrm{kg} \mathrm{cow}^{-1} \mathrm{yr}^{-1}\right)$} & \multicolumn{3}{|c|}{ Recovery fraction $(\%)$} & \multicolumn{3}{|c|}{ Recyclable nutrients $\left(\mathrm{Gg} \mathrm{yr}^{-1}\right)$} \\
\hline & & $\mathrm{N}$ & $\mathrm{P}$ & $\mathrm{K}$ & $\mathrm{N}$ & $\mathrm{P}$ & $\mathrm{K}$ & $\mathrm{N}$ & $\mathrm{P}$ & $\mathrm{K}$ \\
\hline \multirow[t]{6}{*}{ Addis Ababa } & 1 & 25 & 5 & 25 & 0.3 & 0.6 & 0.5 & 0.5 & 0.2 & 0.9 \\
\hline & 2 & 25 & 5 & 25 & 0.5 & 0.8 & 0.7 & 0.9 & 0.3 & 1.2 \\
\hline & 3 & 50 & 10 & 50 & 0.3 & 0.6 & 0.5 & 1.1 & 0.4 & 1.8 \\
\hline & 4 & 50 & 10 & 50 & 0.5 & 0.8 & 0.7 & 1.8 & 0.6 & 2.5 \\
\hline & 5 & 75 & 15 & 75 & 0.3 & 0.6 & 0.5 & 1.6 & 0.6 & 2.6 \\
\hline & 6 & 75 & 15 & 75 & 0.5 & 0.8 & 0.7 & 2.6 & 0.8 & 3.7 \\
\hline \multirow[t]{6}{*}{ Jimma } & 1 & 25 & 5 & 25 & 0.3 & 0.6 & 0.5 & 0.04 & 0.02 & 0.07 \\
\hline & 2 & 25 & 5 & 25 & 0.5 & 0.8 & 0.7 & 0.07 & 0.02 & 0.10 \\
\hline & 3 & 50 & 10 & 50 & 0.3 & 0.6 & 0.5 & 0.09 & 0.03 & 0.14 \\
\hline & 4 & 50 & 10 & 50 & 0.5 & 0.8 & 0.7 & 0.14 & 0.05 & 0.20 \\
\hline & 5 & 75 & 15 & 75 & 0.3 & 0.6 & 0.5 & 0.13 & 0.05 & 0.22 \\
\hline & 6 & 75 & 15 & 75 & 0.5 & 0.8 & 0.7 & 0.22 & 0.07 & 0.30 \\
\hline
\end{tabular}

$\mathrm{Gg}=$ gigagram $=1$ million $\mathrm{kg}$

Table 5 Number of crop farms and estimated total N, P and K demands by crops grown in the urban (zone A), peri-urban (zone B) and rural areas (zone C) of Addis Ababa and Jimma

\begin{tabular}{|c|c|c|c|c|c|c|c|c|}
\hline \multirow[t]{3}{*}{ Areas (Zones) } & \multicolumn{4}{|l|}{ Addis Ababa } & \multicolumn{4}{|l|}{ Jimma } \\
\hline & \multirow[t]{2}{*}{ Number of farms } & \multicolumn{3}{|c|}{ Total demand $\left(\mathrm{Gg}\right.$ year $\left.^{-1}\right)$} & \multirow[t]{2}{*}{ Number of farms } & \multicolumn{3}{|c|}{ Total demand $\left(\mathrm{Gg}\right.$ year $\left.^{-1}\right)$} \\
\hline & & $\mathrm{N}$ & $\mathrm{P}$ & $\mathrm{K}$ & & $\mathrm{N}$ & $\mathrm{P}$ & $\mathrm{K}$ \\
\hline Urban (A) & 1097 & 0.11 & 0.02 & 0.10 & 1417 & 0.11 & 0.02 & 0.09 \\
\hline Peri-urban (B) & 14,435 & 3.63 & 0.52 & 3.11 & 1770 & 0.27 & 0.04 & 0.23 \\
\hline Rural (C) & 12,199 & 3.15 & 0.45 & 2.70 & 1018 & 0.18 & 0.03 & 0.15 \\
\hline Total & 27,731 & 6.89 & 0.99 & 5.91 & 4205 & 0.56 & 0.08 & 0.48 \\
\hline
\end{tabular}

supplied sufficient manure $\mathrm{P}$ from urban livestock farms to match the $\mathrm{P}$ demand in the peri-urban area. Conversely, there is a large oversupply of $\mathrm{P}$ and $\mathrm{K}$, if the $\mathrm{N}$ demand by the crop determines the manure application rates (Fig. 2b). Note, there is also oversupply of $\mathrm{P}$ and $\mathrm{K}$ in the peri-urban area in variant 6 (and partly in variant 5), and there is no manure transport to the rural areas in the balanced $\mathrm{N}$ fertilization strategy.

Rather similar results were obtained for Jimma. For balanced $P$ fertilization, 5 of the 6 variants supplied sufficient manure $\mathrm{P}$ to meet the demand for $\mathrm{P}$ in the urban area (not shown). Variant 6 supplied also sufficient manure $\mathrm{P}$ to meet the demand for $\mathrm{P}$ in the peri-urban area, and also $40 \%$ of the $\mathrm{P}$ demand in the rural area, but demands for $\mathrm{N}$ and $\mathrm{K}$ were not matched in urban, peri-urban and rural areas. For balanced $\mathrm{N}$ fertilization, 3 of the 6 variants (4, 5 and 6$)$ supplied sufficient manure $\mathrm{N}$ to meet the demand for $\mathrm{N}$ in the urban area (and up to $50 \%$ in the peri-urban area), but at the cost of a large oversupply of $\mathrm{P}$ and $\mathrm{K}$ in the urban area (up to $220 \%$ ).

Recycling benefits

Through the envisaged recycling, the total amounts of $\mathrm{N}, \mathrm{P}$ and $\mathrm{K}$ recovered in manure from urban livestock farms in Addis Ababa is equivalent to 1-4 Gg diammonium phosphate (DAP), 0.7-3.9 Gg urea, and 2.3-9.6 Gg potassium chloride $(\mathrm{KCl})$ fertilizers. 
Fig. 2 Supply of N, P and K from urban livestock manure relative to demand of $\mathrm{N}, \mathrm{P}$ and $\mathrm{K}$ by crops in urban farms (zone A), periurban farms (zone B) and rural farms (zone $\mathrm{C}$ ), as function of 6 variants (combinations of excretion coefficients and recovery fraction; see Table 4) in Addis Ababa. Upper graph (a): demand for phosphorus determines manure application rates (balanced $\mathrm{P}$ fertilization), first in urban areas, then peri-urban and finally rural areas. Lower graph (b): demand for nitrogen determines manure application rates (balanced $\mathrm{N}$ fertilization)

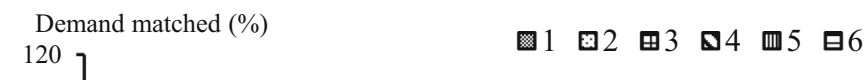

(a)
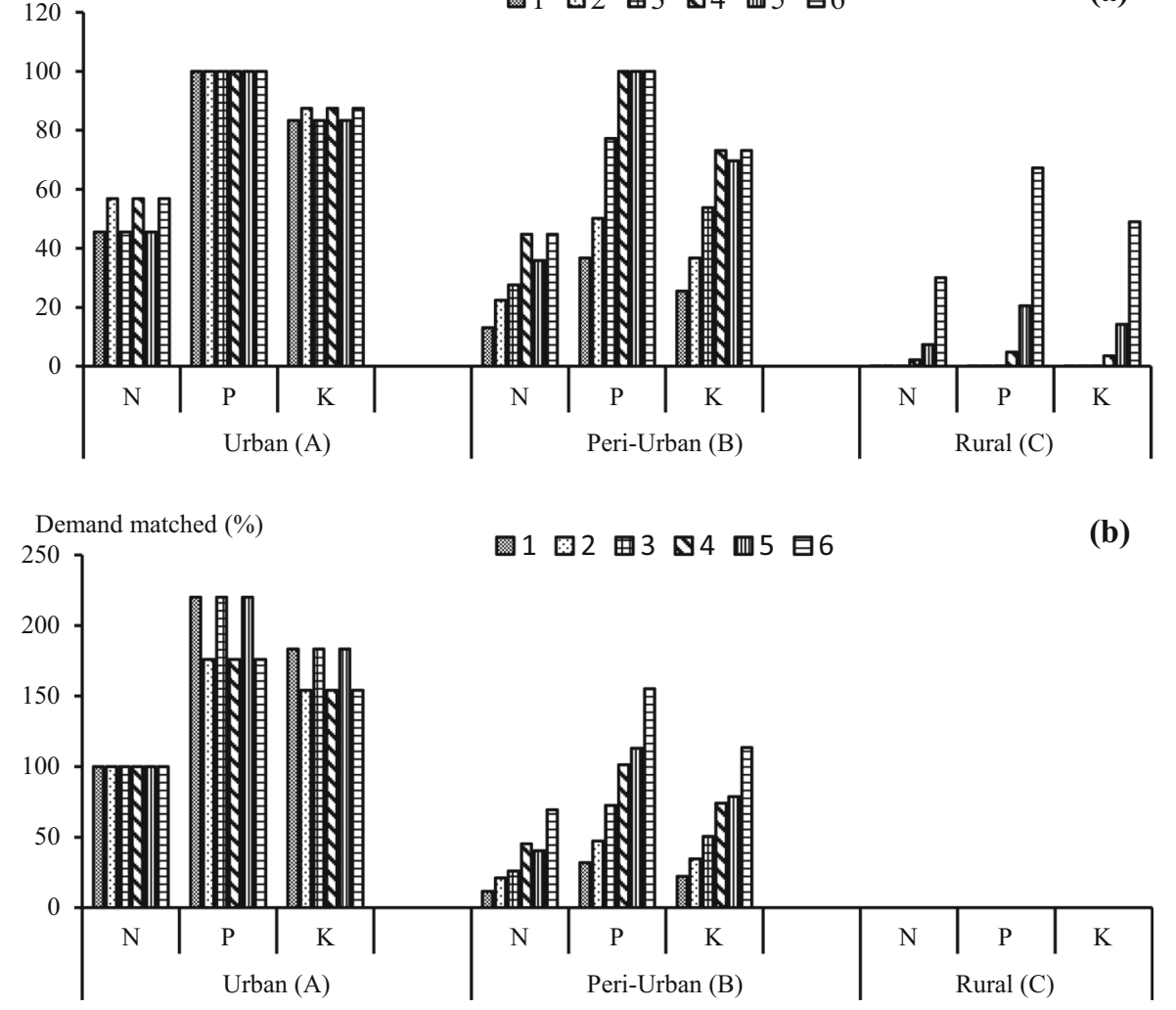

Table 6 Amounts of N, P and K recycled, and cost of synthetic fertilizers saved through recycling of manure from urban livestock farms to crop farms in urban, peri-urban and rural areas of Addis Ababa and Jimma. Ranges reflect the uncertainties in the amounts of manure recycled (Table 4)

\begin{tabular}{|c|c|c|c|c|c|c|c|}
\hline \multirow[t]{2}{*}{ Cities } & \multicolumn{3}{|c|}{ Manure nutrients recycled $\left(\mathrm{Gg} \mathrm{yr}^{-1}\right)$} & \multicolumn{3}{|c|}{ Fertilizer equivalents saved $\left(\mathrm{Gg} \mathrm{yr}^{-1}\right)$} & \multirow[t]{2}{*}{ Savings (million ETB $\mathrm{yr}^{-1}$ ) } \\
\hline & $\mathrm{N}$ & $\mathrm{P}$ & $\mathrm{K}$ & Urea & DAP & $\mathrm{KCl}$ & \\
\hline Addis Ababa & $0.5-2.6$ & $0.2-0.8$ & $0.9-3.7$ & $0.7-3.9$ & $1-4$ & $2.3-9.6$ & $75-300$ \\
\hline Jimma & $0.04-0.22$ & $0.02-0.07$ & $0.07-0.3$ & $0.1-0.3$ & $0.1-0.4$ & $0.2-0.8$ & $6-24$ \\
\hline
\end{tabular}

1000 Ethiopian Birr $($ ETB $)=30$ US\$

Similarly, the recycling of manure from urban livestock farms in Jimma may save $0.1-0.3 \mathrm{Gg}$ DAP, $0.1-0.4 \mathrm{Gg}$ urea and $0.2-0.8 \mathrm{Gg} \mathrm{KCl}$ fertilizers per year. These amounts are equivalent to savings of 75-300 and 6-24 million Ethiopian Birr (ETB), respectively (Table 6). In addition, some 5-50 Gg organic carbon in Addis Ababa and 0.6-6 Gg organic $\mathrm{C}$ in Jimma will be returned with the manure to soil, which is equivalent to roughly 1 to $2 \mathrm{Mg} \mathrm{ha}^{-1}$ (assuming $\mathrm{C} / \mathrm{N}$ ratios that range from 10 to 20 ; Snijders et al. (2009)). Further, an unknown amount of basic cations and secondary nutrients $(\mathrm{Ca}, \mathrm{Mg}, \mathrm{S})$ and micro nutrients (e.g. $\mathrm{Zn}, \mathrm{Cu}$ ) will be returned with the manure to cropland, which are essential for growth and development of crops, animals and humans (Berkhout et al. 2017).

There are additional environmental benefits, because much less manure nutrients (e.g., 0.5-2.6 $\mathrm{Gg} \mathrm{N}$ and 0.2-0.8 Gg P in Addis Ababa) from urban livestock farms pollute the urban environments. 


\section{Discussion}

Urban agriculture and nutrient balances

Urban livestock farms are important for providing nutritious food, jobs and income, but the environmental costs of manure nutrient accumulation and soil and water pollution, and the risks of pathogen transfer and zoonosis are relatively high (Steinfield et al. 2010; Herrero et al. 2018; Khumalo and Sibanda 2019). Both, its importance and the concerns are increasing, because urbanization is increasing, and associated with changes toward more animal-sourced diets. Traditionally, animals are and have been kept for different reasons and animals often have multiple functions. As a consequence, there is a huge diversity in urban livestock farming, which roughly falls in three main categories, i.e. (i) back yard/subsistence/ small mixed farms, (ii) intensive/industrial/large animal feeding operations, and (iii) company/leisure/care pets and horses (Robinson et al. 2011). Urban livestock farms in Ethiopia mainly fall in the first category, but the livestock sector is rapidly changing and in transition.

There were about 5200 livestock farms with on average 0.6 ha of land and 13.5 TLU per farm in the urban zone of Addis Ababa. These farms produced $560-1690 \mathrm{~kg} \mathrm{~N}, \quad 113-338 \mathrm{~kg} \mathrm{P}$ and $560-1690 \mathrm{~kg} \mathrm{~K} \mathrm{ha}^{-1} \mathrm{yr}^{-1}$ in manure, which is much more than can be taken up by most crops, as follows also from the relatively large $\mathrm{N}, \mathrm{P}$ and $\mathrm{K}$ surpluses of urban livestock farms (Table 3). Even when the recovery fractions of $30-50 \%$ for $\mathrm{N}, 60-80 \%$ for $\mathrm{P}$ and 50-70\% for $\mathrm{K}$ were taken into account, amounts of manure nutrients available for the limited area of crop land on the farm remain much higher than what can be taken up by most crops.

Though the urban livestock farms were much wealthier than other farms in the urban, peri-urban and rural areas (Table 2), these farms were still small compared to many urban and peri-urban livestock farms in emerging markets economies such as China (Steinfield et al. 2010; Wei et al. 2016). These factory farms or confined animal feeding operations often have thousands of pigs or hundreds of dairy cows, and also have little or no land for manure disposal, and thereby create serious air, water and soil pollution (Bai et al. 2018). However, our data suggest that 5200 small livestock farms together may create rather similar manure nutrient surpluses in Addis Ababa as the few hundred large pig farms around Beijing do (Wei et al. 2016). The difference is that the small livestock farms in Addis Ababa are diffusively spread and perhaps less visible.

There were nearly 5 times less crop farms (1100) than livestock farms in the urban zone (Table 5). These crop farms had on average 1.7 ha of land and 4 TLU per farm (Table 2), and had negative $\mathrm{N}$ and $\mathrm{K}$ balances and slightly positive $\mathrm{P}$ balances (Table 3 ), despite 2 TLU ha ${ }^{-1}$. Likely, most feed was produced on-farm and little imported, because mixed farms with relatively large area of crop land invest relatively little in animal production (Tadesse et al. 2019); the N, P and $\mathrm{K}$ excretion coefficients applicable for the livestock in these mixed crop farms were likely at the lower end of the range used in our calculations (Table 4). The negative $\mathrm{N}$ and $\mathrm{K}$ balances indicate that there was little exchange of manure between livestock farms and crop farms in the urban zone; crop farms with nutrient depletion co-existed next to livestock farms with large manure nutrient surpluses. Though crop farmers know the value of manure for crop production, there is need for education and extension services that encourage exchange and interaction between farmers for increasing adoption of good manure management practices (Ndambi et al. 2019). Lack of knowledge and clear guidelines were also identified as main reasons for poor nutrient management practices of urban gardeners in The Netherlands (Wielemaker et al. 2019).

Manure recycling between urban livestock farms and crop farms

Manure is a heterogeneous product and the composition is not known in practice, generally. The heterogeneity of cattle manure is related to variations in the composition of the diet, in nutrient retention in animal production, and in losses during storage. Snijders et al. (2009) reviewed literature on the composition of cattle manure in east Africa, and based on their review we derived the following composition (mean \pm standard deviation; $\mathrm{n}>20): 1.7 \pm 0.7 \% \mathrm{~N} ; 0.5 \pm 0.3 \% \mathrm{P}$ and $1.8 \pm 1.3 \% \mathrm{~K}$, with a N/P ratio of $4.1 \pm 1.7$ and a K/P ratio of $4.6 \pm 2.7$ (medians were 3.8 and 3.6, respectively). The ratios for manures estimated in our study $(\mathrm{N} / \mathrm{P}=2.5-3.1$ and $\mathrm{K} / \mathrm{P}=4.2-4.4$; derived from Table 4) fall in the lower half of the indicated ranges, 
suggesting that our manures were relatively $\mathrm{N}$ and $\mathrm{K}$ poor and/or P rich (Rufino et al. 2014).

In total $0.5-2.6 \mathrm{Gg} \mathrm{N}, 0.2-0.8 \mathrm{Gg} \mathrm{P}$ and $0.9-3.7 \mathrm{Gg}$ $\mathrm{K}$ can be recovered in manure from urban livestock farms in Addis Ababa (Table 4), and utilized in crop farms in urban and peri-urban zones, following the 'balanced P fertilization' or 'balanced $\mathrm{N}$ fertilization' strategies (Fig. 2). Balanced $\mathrm{P}$ fertilization assumes that the crop $\mathrm{P}$ demand is met through manure, and that synthetic $\mathrm{N}$ and $\mathrm{K}$ fertilizers (or other nutrient sources) should be used to top up, to match the remaining $\mathrm{N}$ and $\mathrm{K}$ demands. Balanced $\mathrm{N}$ fertilization assumes that the crop $\mathrm{N}$ demand is met through manure and that $\mathrm{P}$ and $\mathrm{K}$ demands are also met. Balanced $\mathrm{N}$ fertilization led to a relative oversupply of $\mathrm{P}$ and $\mathrm{K}$ (Fig. 2), and to less manure transport and distribution than balanced $\mathrm{P}$ fertilization. Balanced $\mathrm{P}$ fertilization is a better strategy from nutrient management perspective, as it allows for greater precision through matching supply and demand for all three nutrients.

We made no corrections for the fertilizer $\mathrm{N}$ effectiveness value of the manure (defined as the fraction of manure $\mathrm{N}$ that has similar effect as common synthetic $\mathrm{N}$ fertilizer). This value may range from 0.3 to 1.0 depending on the composition and application rate of the manure, and the duration of manure use and accounting for period (Schröder et al. 2007; Zhang et al. 2020). Correcting for the fertilizer $\mathrm{N}$ effectiveness value of the manure would thus have increased the manure application rate in the balanced $\mathrm{N}$ fertilization strategy, and would have led to larger $\mathrm{P}$ and $\mathrm{K}$ over fertilization. The $\mathrm{P}$ and $\mathrm{K}$ effectiveness values of manure are generally set at 1 (equal to high-grade synthetic P and K fertilizers; Oenema et al. (2012)).

We made no corrections for manure application on crop land of livestock farms, and for manure production by livestock on crop farms. In the urban area the demand for $\mathrm{P}$ by the crop in livestock farms was similar to the supply of $\mathrm{P}$ in manure from the livestock in crop farms, and thus cancel each other more or less out. However, by neglecting the nutrient demand by the crop of livestock farms, and the nutrient supply in the manure produced in crop farms, we overestimated the need for manure transport and redistribution. Hence, such corrections should be made in future studies.

The estimated amounts of manure that may be recovered on urban livestock farms in Addis Ababa are rather similar to the amounts that may be recovered from urban livestock farms in other large cities in East Africa. De Zeeuw et al. (2011) reported that $2.2 \mathrm{Gg} \mathrm{N}$, 2.2 Gg P and $3.7 \mathrm{Gg} \mathrm{K}$ could be recovered from manure and waste in Nairobi. Komakech (2014) reported rather similar numbers for urban cattle manure in Kampala, and estimated also significant synthetic fertilizer savings. Though significant, the amounts of $\mathrm{N}$ and $\mathrm{P}$ produced in cattle manure in urban farms are about one order of magnitude lower than the total $\mathrm{N}$ and $\mathrm{P}$ excretion by the human population in Addis Ababa. When assuming a mean protein $\mathrm{N}$ intake of $3 \mathrm{~kg}$ and a $P$ intake of $0.6 \mathrm{~kg}$ capita $^{-1}$, the annual total $\mathrm{N}$ and $\mathrm{P}$ in human waste production will be about $10 \mathrm{Gg} \mathrm{N}$ and $2 \mathrm{Gg}$ P. However, the recovery and recycling of $\mathrm{N}, \mathrm{P}$ and $\mathrm{K}$ from human wastes are complicated, although there is an increasing need to do so (Hodson et al. 2012; Guerrero et al. 2013).

Recycling benefits and barriers

Urban manure recovery and recycling may have energy, economic and environmental benefits, the 3Es aspects (Rodionov and Nakata (2011). Estimated fertilizer saving for Addis Ababa were in the range of 75 to 300 million Ethiopian Birr (Table 6). Additional benefits relate to replenishing nutrients in crop land and to improving soil quality and nutrient balances (McConville et al. 2017; Szogi et al. 2015). More difficult to-account-for benefits include reductions in the pollution of soil, surface waters and groundwater, and in the threat of food safety, human health and biodiversity loss (Wen et al. 2017).

Though beneficial, manure recycling is not practiced in the study urban regions at present as shown by Tadesse et al. (2018) who reported that landless cLS (commercial livestock) farms with surplus LSM (livestock manure), simply dumped large quantity of LSM into ditches and farm surroundings or left it unmanaged on the ground. Similarly, in Kampala city, many livestock farms discard and dumped LSM into drainage channels, where it is carried off by running water, because there is no comprehensive national urban policy and institutional framework to regulate the use of solid waste (Komakech 2014). In addition to losses of nutrient resources, unmanaged wastes may contribute to pollution of the urban environment (Wen et al. 2017). Where waste is managed, Nigussie et al. (2015) reported that large quantity of waste was dumped in landfills in these urban areas. Landfilling of 
organic wastes contribute to pollution issues related to landfill leachate and gas as well as the loss of valuable nutrients and organic matter. There are many factors leading to these outcomes as Marshall and Farahbakhsh (2013) citing cultural, socioeconomic, governance and institutional aspects limiting solid waste management in many developing countries. There are currently no incentives or policies to encourage the recycling of LSM from urban farms to crop farms in the study urban regions. Guerrero et al. (2013) and Komakech (2014) reported the absence of satisfactory policies or mere presence of weak policies and regulations as the critical causes for the failed solid waste management systems in low-income countries. Shortage of land and lack of tenure rights in urban LS farms (Table 2) for manure use or disposal, lack of appropriate institutions and poor infrastructures in the study urban regions are also barriers for LSM recycling. Guerrero et al. (2013) stated as success of recycling depends on the efficiency of infrastructures. Improving animal housing and LSM storage conditions, may reduce nutrient losses and increase the nutrient recovery and thus can maximize the potential of recycling LSM nutrients.

Further, the possible presence of pathogens, pharmaceutical compounds and veterinary products such as hormones and antibiotics in manure are sometimes seen as additional barriers for recycling (Manyi-Loh et al. 2016; Hou et al. 2017; Martens and Bohm 2009). These barriers could be addressed through anaerobic digestion and/or composting (Cliver 2009; Manyi-Loh et al. 2016). Evidently, recycling manure from urban to peri-urban and rural areas requires awareness raising, guidelines and protocols, and appropriate institutions, incentives and advisory services (Mulugeta 2013). In the end, it requires also careful monitoring and control. Thus, policymakers and stakeholders should promote manure reuse through incentives, technologies and appropriate strategies and policies, to improve nutrient use and reduce the pollution of the environment (Herrero et al. 2018).

\section{Limitations and uncertainties of our study}

Coupling livestock production to crop production via direct exchanges of animal feed and animal manure is key for increasing the sustainability of food production systems. In our study, we focused on the recycling of manure from urban livestock farms to crop farms only. Though livestock farms and crop farms were visited twice, there is as yet little accurate quantitative information about animal feed origin and rations and animal productivity. Hence, we have no accurate information about $\mathrm{N}, \mathrm{P}$ and $\mathrm{K}$ excretion rates and $\mathrm{N}, \mathrm{P}$ and $\mathrm{K}$ contents of recovered manures. We addressed this uncertainty through using ranges (Table 4). Uncertainties arise also from the uncertainties in crop areas and number of farms and animals. Further, the N, $\mathrm{P}$ and $\mathrm{K}$ demand of crops were derived from MonQIt, which is a static model and does not account for seasonal variations in N, P and $\mathrm{K}$ demand and supply, (e.g., Krause and Rotter (2018)).

The livestock sector responds to changes in markets and the availability of new technology, which are influenced subsequently by urbanization and globalization. Though livestock farms in the urban zones of Addis Ababa and Jimma are still relatively small compared to farms in for example east Asia, it cannot be excluded that rapid changes may occur. This calls for more dynamic approaches including considerations of long-term effects of manure and fertilizer applications on soil fertility level and the response of crops to these changes (Zoboli et al. 2016). Further insights may be accomplished through scenario analyses and measurements of feed, manures and soil.

\section{Conclusions}

The $>5000$ livestock farms in the urban zones of Addis Ababa and the 500 livestock farms in Jimma produce more $\mathrm{N}, \mathrm{P}$ and $\mathrm{K}$ in manure than the $>1000$ crop farms in the urban zones of these cities demand for. Yet, crop farms in the urban area have negative $\mathrm{N}$ and $\mathrm{K}$ balances (but positive $\mathrm{P}$ balances because of subsidized fertilizers) and use little or no manure from livestock farms. We estimated how much N, P and $\mathrm{K}$ in manure may be recovered in urban livestock farms, and how much may be used in urban, peri-urban and rural crop farms.

A balanced $\mathrm{P}$ fertilization strategy was preferred to a balanced $\mathrm{N}$ fertilization strategy for estimating the allocation of manure in crop farms. The former will require a top-up with $\mathrm{N}$ and $\mathrm{K}$ from other nutrient sources, while the latter will lead to over fertilization with $\mathrm{P}$ and $\mathrm{K}$, especially on the long term.

Recycling manure from urban livestock farms to crop farms has several benefits, including fertilizer 
savings, nutrient replenishment in crop land, restoring nutrient balances, and minimizing soil, air and water pollution. However, lack of knowledge, advisory services, and policy incentives, and cultural and institutional barriers appear to prevent cashing in these benefits. There is also a significant uncertainty in the estimated benefits, due to lack of accurate data. Our study may help policy makers to prioritize and define research and policies related to re-connecting animal production and crop production systems through manure recycling in the urban environment. Further studies should focus on collecting quantitative data related to improving the performances of animal and crop production systems in the urban area, and should explore more sustainable development pathways.

Acknowledgements This study was part of the CASCAPE Project (Capacity building for scaling up of evidence-based best practices in agricultural production in Ethiopia). The Project is funded by the Dutch Ministry of Foreign Affairs through the Embassy of the Kingdom of The Netherlands in Addis Ababa, Ethiopia (grant No: 5120915001). We are also grateful to the staff of Addis Ababa and Jimma urban Agriculture offices for facilitating field data collection.

Open Access This article is licensed under a Creative Commons Attribution 4.0 International License, which permits use, sharing, adaptation, distribution and reproduction in any medium or format, as long as you give appropriate credit to the original author(s) and the source, provide a link to the Creative Commons licence, and indicate if changes were made. The images or other third party material in this article are included in the article's Creative Commons licence, unless indicated otherwise in a credit line to the material. If material is not included in the article's Creative Commons licence and your intended use is not permitted by statutory regulation or exceeds the permitted use, you will need to obtain permission directly from the copyright holder. To view a copy of this licence, visit http://creativecommons.org/licenses/by/4.0/.

\section{References}

Abdalla SB, Predotova M, Gebauer J, Buerkert A (2011) Horizontal nutrient flows and balances in irrigated urban gardens of Khartoum, Sudan. Nutr Cycl Agroecosyst 92:119-132

Abebe MS, Derebew KT, Gemeda DO (2019) Exploiting temporal-spatial patterns of informal settlements using GIS and remote sensing technique: a case study of Jimma city, Southwestern Ethiopia. Environ Syst Res 8(1):6
Abrha C, Feyisa GL, Feyssa DH (2015) Analysis of land use/cover dynamics in Jimma city, Southwest Ethiopia: an application of satellite remote sensing. EJAST 6:24-34

Admasu TG, Runnstrom M (2017) Monitoring trends of greenness and LULC (land use/land cover) change in Addis Ababa and its surrounding using MODIS time-series and LANDSAT Data. MSc Thesis, Department of Physical Geography and Ecosystem Science Lund University (pp. 60)

Allen A (2003) Environmental planning and management of peri-urban interface: perspectives on an emerging field. Environ Urban 15:135-147

Alvarez S, Rufino MC, Vayssières J, Salgado P, Tittonell P, Tillard E, Bocquier F (2014) Whole-farm nitrogen cycling and intensification of crop-livestock systems in the highlands of Madagascar: An application of network analysis. Agric Syst 126:25-37

Bai Z, Ma W, Ma L, Velthof GL, Wei Z, Havlík P, Oenema O, Lee MRF, Zhang F (2018) China's livestock transition: driving forces, impacts, and consequences. Sci Adv 4(7):8534

Bekunda M, Manzi G (2003) Use of the partial nutrient budget as an indicator of nutrient depletion in the highlands of southwestern Uganda. Nutr Cycl Agroecosyst 67:187-195

Berkhout E, Malan M, Kram T (2017) Micronutrients for agricultural intensification - Is Sub-Saharan Africa at risk? PBL publication 1946. Netherlands Environmental Assessment Agency, The Hague

Bicudo JR (2009) Animal Solid Manure: storage Handling and Disposal. In: Mcnulty P, Parick MG (eds) Agricultural Mechanization And Automation. Encyclopedia of Life Support Systems (EOLSS) Publisher Co Ltd, Oxford

Buckwell A, Nadeu E (2016) Nutrient Recovery and Reuse (NRR) in European agriculture. A review of the issues, opportunities, and actions. RISE Foundation, Brussels.

Chihambakwe M, Mafongoya P, Jiri O (2018) Urban and periurban agriculture as a pathway to food security: a review mapping the use of food sovereignty. Challenges 10(1):6

Cliver DO (2009) Disinfection of animal manures, food safety and policy. Bioresour Technol 100:5392-5394

De Zeeuw H, van Veenhuizen R, Dubbeling M (2011) The role of urban agriculture in building resilient cities in developing countries. J Agric Sci 149:153-163

Djurfeldt AA (2015) Urbanization and linkages to smallholder farming in sub-Saharan Africa: implications for food security. Glob Food Secur 4:1-7

Eyasu E, van Beek CL (2015) Scaling innovations and agricultural best practices in ethiopia: experiences and challenges. Proceedings of the CASCAPE national stakeholder conference, 23-24 April 2014. Addis Ababa. Ethiopia. CASCAPE Project, Wageningen University and Research Centre (WUR), Wageningen, The Netherlands

FAO (2017) The future of food and agriculture-Trends and challenges. Rome

Feyisa GL, Meilby H, Darrel Jenerette G, Pauliet S (2016) Locally optimized separability enhancement indices for urban land cover mapping: exploring thermal environmental consequences of rapid urbanization in Addis Ababa, Ethiopia. Remote Sens Environ 175:14-31 
Goulding K, Jarvis S, Whitmore A (2008) Optimizing nutrient management for farm systems. Philos Trans R Soc Lond B Biol Sci 363:667-680

Guerrero LA, Maas G, Hogland W (2013) Solid waste management challenges for cities in developing countries. Waste Manag 33:220-232

Herrero MA et al (2018) Dairy manure management perceptions and needs in South American countries. Front Sustain Food Syst 2:22

Hodson M, Marvin S, Robinson B, Swilling M (2012) Reshaping urban infrastructure. J Ind Ecol 16:789-800

Hou Y, Velthof GL, Lesschen JP, Staritsky IG, Oenema O (2017) Nutrient recovery and emissions of ammonia, nitrous oxide, and methane from animal manure in Europe: effects of manure treatment technologies. Environ Sci Technol 51:375-383

Jones DL, Cross P, Withers PJA, Deluca TH, Robinson DA, Quilliam RS, Harris IM, Chadwick DR, Edwards-Jones G, Kardol P (2013) REVIEW: nutrient stripping: the global disparity between food security and soil nutrient stocks. J Appl Ecol 50:851-862

Khumalo N, Sibanda M (2019) Does urban and peri-urban agriculture contribute to household food security? an assessment of the food security status of households in Tongaat, ethekwini municipality. Sustainability 11:819-822

Komakech AJ (2014) Urban waste management and the environmental impact of organic waste treatment systems in Kampala Uganda Phd. Swedish University of agricultural sciences, Uppsala and Makerere university, Kampala

Krause A, Rotter V (2018) Recycling improves soil fertility management in smallholdings in tanzania. Agriculture 8:31

Lin T, Gibson V, Cui S, Yu CP, Chen S, Ye Z, Zhu YG (2014) Managing urban nutrient biogeochemistry for sustainable urbanization. Environ Pollut 192:244-250

Liu Q, Wang J, Bai Z, Ma L, Oenema O (2017) Global animal production and nitrogen and phosphorus flows. Soil Res $55: 451$

Lupindu AM (2017) Public health aspect of manure management in urban and peri-urban livestock farming in developing countries. Livestock Science 15:40

Makita K, Fevre EM, Waiswa C, Bronsvoort MD, Eisler MC, Welburn SC (2010) Population-dynamics focussed rapid rural mapping and characterisation of the peri-urban interface of Kampala, Uganda. Land Use Policy 27:888-897

Manyi-Loh CE, Mamphweli SN, Meyer EL, Makaka G, Simon M, Okoh AI (2016) An overview of the control of bacterial pathogens in cattle manure. Int J Environ Res Pub Health 13:843

Marshall RE, Farahbakhsh K (2013) Systems approaches to integrated solid waste management in developing countries. Waste Manag 33:988-1003

Martens W, Bohm R (2009) Overview of the ability of different treatment methods for liquid and solid manure to inactivate pathogens. Bioresour Technol 100:5374-5378

McConville J, Drangert J-O, Tidaker P, Neset T-S, Rauch S, Strid I, Tonderski K (2017) Closing the food loops: guidelines and criteria for improving nutrient management. Sustain Sci Pract Policy 11:33-43
Michelini G, Moraes RN, Cunha RN, Costa JMH, Ometto AR (2017) From linear to circular economy: PSS conducting the transition. Procedia CIRP 64:2-6

Mohamed A, Worku H (2019) Quantification of the land use/land cover dynamics and the degree of urban growth goodness for sustainable urban land use planning in Addis Ababa and the surrounding Oromia special zone. J Urban Manag 8(1):145-158

Mugisa IO et al (2017) Urban and peri-urban crop farming in central Uganda: characteristics, constraints and opportunities for household food security and income. Afr J Plant Sci 11:264-275

Mukai S (2018) Historical role of manure application and its influence on soil nutrients and maize productivity in the semi-arid Ethiopian Rift Valley. Nutr Cycl Agroecosyst 111:9913

Mulugeta M (2013) The need for policy framework for urban/ peri-urban agriculture in Ethiopia: a reflection. EJOSSAH 9:79-109

Ndambi OA, Pelster DE, Owino JO, de Buisonjé F, Vellinga T (2019) Manure management practices and policies in subSaharan Africa: implications on manure quality as a fertilizer. Front Sustain Food Syst 3:29

Negash D, Abegaz A, Smith JU, Araya H, Gelana B (2017) Household energy and recycling of nutrients and carbon to the soil in integrated crop-livestock farming systems: a case study in Kumbursa village, Central Highlands of Ethiopia. GCB Bioenergy 9:1588-1601

Neo H (2010) The potential of large-scale urban waste recycling: a case study of the national recycling programme in Singapore. Soc Nat Resour 23:872-887

Nigussie A, Kuyper TW, de Neergaard A (2015) Agricultural waste utilisation strategies and demand for urban waste compost: Evidence from smallholder farmers in Ethiopia. Waste Manage 44:82-93

Oenema O, Chardon WJ, Ehlert PAI, van Dijk KC, Schoumans OF, Rulkens WH (2012) Phosphorus fertilisers from byproducts and wastes. Proceeding 717. International Fertiliser Society, Leek, p. 1-55. Research output: Contribution to conference, Conference paper, Academic

Opitz I, Berges R, Piorr A, Krikser T (2015) Contributing to food security in urban areas: differences between urban agriculture and peri-urban agriculture in the Global North. Agric Hum Val 33:341-358

Pergola M, Persiani A, Palese AM, Di Meo V, Pastore V, D'Adamo C, Celano G (2018) Composting: the way for a sustainable agriculture. Appl Soil Ecol 123:744-750

Rao K, Otoo M, Drechsel P, Hanjra M (2017) Resource recovery and reuse as an incentive for a more viable sanitation service chain. Water Altern 10:493-512

Robinson TP, Thornton PK, Franceschini G, Kruska RL, Chiozza F, Notenbaert A, Cecchi G, Herrero M, Epprecht M, Fritz S, You L, Conchedda G, See, L (2011). Global livestock production systems. Food and Agriculture Organization of the United Nations (FAO) and International Livestock Research Institute (ILRI), $152 \mathrm{pp}$

Rodionov M, Nakata T (2011) Design of an optimal waste utilization system: a case study in St. Petersburg. Russia Sustain 3:1486-1509

Roessler R, Mpouam S, Muchemwa T, Schlecht E (2016) Emerging development pathways of urban Livestock 
Production in rapidly growing West Africa Cities. Sustainability $8: 1199$

Rufino MC, Tittonell P, Van Wijk MT, Castellanos-Navarrete A, Delve RJ, De Ridder N, Giller KE (2007) Manure as a key resource within smallholder farming systems: analyzing farm-scale nutrient cycling efficiencies with the NUANCES framework. Livest Sci 112:273-287

Rufino MC, Brandt P, Herrero M, Butterbach-Bahl K (2014) Reducing uncertainty in nitrogen budgets for African livestock systems. Environ Res Lett 9(10):1748

Satterthwaite D (2017) The impact of urban development on risk in sub-Saharan Africa's cities with a focus on small and intermediate urban centres. Int J Disaster Risk Reduct 26:16-23

Schröder JJ, Uenk D, Hilhorst GJ (2007) Long-term nitrogen fertilizer replacement value of cattle manures applied to cut grassland. Plant Soil 299:83-99

Sheldrick SJK, Lingard J (2003) Contribution of livestock excreta to nutrient balances. Nutr Cycl Agroecosyst 66:119-131

Simon D (2008) Urban Environments: issues on the peri-urban fringe. Annu Rev Environ Resour 33:167-185

Smaling EMA, Lesschen JP, van Beek CL, De Jager A, Stoorvogel JJ, Batjes NH, Fresco LO (2013) Where do we stand 20 years after the assessment of soil nutrient balances in sub-Saharan Africa? In: Lal R, Steart BA (eds) World SOIL RESOURCES and FOOD SECURITY. CRC Press, Boca Raton

Smits M-J, Woltjer G (2018) Phosphorus recycling from manure: a case study on the circular economy. Deliverable 4:61

Snijders P, Onduru D, Wouters B, Gachimbi L, Zake J, Ebanyat P, Ergano K, Abduke M, van Keulen M (2009) Cattle manure management in East Africa: Review of manure quality and nutrient losses and scenarios for cattle and manure management. Report 258, Wageningen Livestock Research. ISSN, 1570-8616

Steinfield H, Mooney HA, Schneider F, Neville LE (eds) (2010) Livestock in a changing landscape-drivers, consequences, and responses. Island Press, London, p 396

Sutton AL (1994) Proper animal manure utilization 39. J Soil Water Conserv 39:65-70

Szogi AA, Vanotti MB, Ro KS (2015) Methods for treatment of animal manures to reduce nutrient pollution prior to soil application. Curr Pollut Report 1:47-56

Tabor KW (2013) Land use and land cover dynamic, socioeconomic and environmental transformations and implications: A geographical study of the fringe of Finfinnee (Addis Ababa) city, Ethiopia. PhD Thesis at Department of geography, Osmania University Hyderabad-500007, India: 422

Tadesse ST, Oenema O, van Beek CL, Ocho FL (2018) Diversity and nutrient balances of urban and peri-urban farms in Ethiopia. Nutr Cycl Agroecosyst 111:1-18

Tadesse ST, Oenema O, van Beek C, Ocho FL (2019) Nitrogen allocation and recycling in peri-urban mixed crop-livestock farms in Ethiopia. Nutr Cycl Agroecosyst 115(2):145-158

Tamiru M, Amza N (2017) Review on the status of dairy cattle production in Ethiopia. J Gene Environ Resour Conserv 5:84-95
Tefera TL, Azage T, Hoekstra D (2012) Capacity for knowledge based smallholder agriculture in Ethiopia: Linking graduate programs to market-oriented agricultural development: Challenges, opportunities and IPMS experience. IPMS (Improving Productivity and Market Success) of Ethiopian Farmers Project Working Paper 29. Nairobi, Kenya, ILRI. www.ilri.org

Terfa BK, Chen N, Liu D, Zhang X, Niyogi D (2019) Urban expansion in Ethiopia from 1987 to 2017: characteristics spatial patterns and driving forces. Sustainability 11(10):2973

Thebo AL, Drechsel P, Lambin EF (2014) Global assessment of urban and peri-urban agriculture: irrigated and rainfed croplands. Environ Res Lett 9:114

UN-DESA (2019) World Urbanization Prospects: The 2018 Revision. 420. United Nations

Van Beek CL, Meerburg BG, Schils RLM, Verhagen J, Kuikman PJ (2010) Feeding the world's increasing population while limiting climate change impacts: linking $\mathrm{N}_{2} \mathrm{O}$ and $\mathrm{CH}_{4}$ emissions from agriculture to population growth. Environ Sci Policy 13:89-96

Van Beek CL, Elias E, Yihenew GS, Heesmans H, Tsegaye A, Feyisa H, Tolla M, Mamuye M, Gebremeskel Y, Mengist S (2016) Soil nutrient balances under diverse agro-ecological settings in Ethiopia. Nutr Cycl Agroecosyst 106:257-274

Vlaming J, van Beek CL, Heinen M, van Duivenbooden N (2012) MonQIt monitoring for quality improvement MonQIt basic user manual. www.monqi.org

Wang F, Wang Z, Kou C, Ma Z, Zhao D (2016) Responses of Wheat Yield, Macro- and micro-nutrients, and heavy metals in soil and wheat following the application of manure compost on the North China Plain. PLoS ONE 11:1-18

Wei S, Bai ZH, Qin W, Xia LJ, Oenema O, Jiang RF, Ma L (2016) Environmental, economic and social analysis of peri-urban pig production. J Clean Product. https://doi.org/ 10.1016/j.jclepro.2016.03.133

Wen Y, Schoups G, Van De Giesen N (2017) Organic pollution of rivers: combined threats of urbanization, livestock farming and global climate change. Sci Rep 7:43289

Wielemaker R, Oenema O, Zeeman G, Weijma J (2019) Fertile cities: nutrient management practices in urban agriculture. Sci Total Environ 668:1277-1288

Yu J, Wu J (2018) The sustainability of agricultural development in China: the agriculture-environment Nexus. Sustainability 10:1776

Yu C, Xiao Y, Ni S (2017) Changing patterns of urban-rural nutrient flows in China: driving forces and options. Sci Bull 62:83-91

Zewdie M, Worku H, Bantider A (2018) Temporal dynamics of the driving factors of urban landscape change of addis ababa during the past three decades. Environ Manag 61:132-146

Zhang X, Fang Q, Zhang T, Ma W, Velthof GL, Hou Y, Oenema O, Zhang F (2020) Benefits and trade-offs of replacing synthetic fertilizers by animal manures in crop production in China: a meta-analysis. Glob Change Biol 26:888-900

Zhu YG, Reid BJ, Meharg AA, Banwart SA, Fu BJ (2017) Optimizing Peri-URban ecosystems (PURE) to re-couple urban-rural symbiosis. Sci Total Environ 586:1085-1090 
Zoboli O, Zessner M, Rechberger H (2016) Supporting phosphorus management in Austria: potential, priorities and limitations. Sci Total Environ 565:313-323
Publisher's Note Springer Nature remains neutral with regard to jurisdictional claims in published maps and institutional affiliations. 